\title{
Spontaneous and hybrid origins of parthenogenesis in Campeloma decisum (freshwater prosobranch snail)
}

\author{
STEVEN G. JOHNSON \\ Museum of Natural History, Department of Systematics and Ecology, The University of Kansas, Lawrence, KS 66045, \\ U.S.A.
}

\begin{abstract}
A previous study hypothesized that parthenogenesis arose spontaneously in the freshwater prosobranch snail, Campeloma decisum, and was subsequently maintained by strong sterility selection against males caused by a digenetic trematode, Leucochloridiomorpha constantiae. The present study examines whether parthenogenesis arose spontaneously or by hybridization between genetically distinct sexual ancestors. Genetic variation was examined at 19 enzyme loci in 11 parthenogenetic and seven sexual populations. Parthenogens from North Carolina and Wisconsin are homozygous at all loci, which suggests that parthenogenesis arose spontaneously in the absence of hybridization. Parthenogens from other northern populations are heterozygous at numerous loci and these individuals have gene combinations found in distinct sexual lineages. These findings suggest that parthenogenesis arose both spontaneously, followed by strong selection of these families from parasitic castration of males, and by hybridization. Low levels of clonal diversity occurred within and among parthenogenetic populations and clonal diversity is derived from patterns of genetic diversity present in sexual populations. Lastly, fixed allelic differences between southeastern and southern sexual individuals suggest that these areas are inhabited by cryptic species.
\end{abstract}

Keywords: Campeloma decisum, clonal diversity, hybridization, parthenogenesis, spontaneous origins.

\section{Introduction}

Study of the origin of parthenogenetic reproduction from sexual ancestors is fraught with problems inherent in the unravelling of historical events. Various mechanisms have been invoked to explain the presence of parthenogenetic taxa within predominately sexual clades. Adaptive hypotheses state that the predominance of parthenogens at high altitudes and latitudes may reflect selection for females capable of parthenogenesis in response to the absence or low density of males during colonization (Stebbins, 1950; Lloyd, 1980 ) or in response to lessened competition or parasitism (Levin, 1975; Glesener \& Tillman, 1978; Lively, 1987). Parthenogenesis is assumed to arise rarely through spontaneous mutation, and the subsequent spread and fixation of parthenogenesis is derived from the selective advantages accrued from reproductive assurance and/or escape from competitors or parasites. Although some sexual females seem capable of parthenogenetic reproduction when males are unavail- able (Carson, 1967; Templeton et al., 1976; Templeton, 1982), modification of gametogenesis without depression of fertility and stable development may be difficult obstacles to overcome during initial stages of parthenogenesis (Moritz et al., 1989a). These genetic constraints may account for the rarity of parthenogenesis. Nonetheless, the study of invertebrate parthenogens has shown consistent patterns of parthenogens being found in disturbed, glaciated regions where male density may be low or where levels of competition and parasitism are lower (Suomalainen \& Saura, 1973; Cuellar, 1977; Suomalainen et al., 1987).

The most common explanation for the origin of parthenogenesis in vertebrates and many invertebrates, however, is hybridization between genetically distant sexual taxa (Schultz, 1969; White, 1973; Hewitt, 1975; Parker \& Selander, 1976; Vrijenhoek, et al., 1977; Moritz, 1983; Dawley \& Bogart, 1989; Honeycutt \& Wilkinson, 1989; Moritz et al., 1989b, 1989c). Numerous parthenogenetic taxa are heterozygous at enzyme loci for which the putative sexual ancestors 
have the opposite allele fixed. This pattern of parthenogens sharing alleles derived from the sexual ancestors is often considered evidence of a direct relationship between hybridization and the origin of parthenogenesis. The mode of origin of parthenogenesis, whether by spontaneous mutation or hybridization, may dramatically affect genotypic diversity and the concomitant evolutionary consequences of parthenogenesis.

This study examines the hypothesis that hybridization between sexual ancestors of Campeloma decisum, a freshwater snail, is a factor in the origin of parthenogenesis by describing patterns of electrophoretic variation of proteins within and among parthenogenetic and sexual populations throughout eastern North America. The primary purpose is to examine whether parthenogens have enzyme profiles consistent with a spontaneous origin of parthenogenesis or with a hybrid origin between genetically distinct sexual ancestors. If parthenogenesis arose spontaneously, parthenogens should have similar or lower levels of polymorphism and heterozygosity relative to their sexual ancestors. The hybrid hypothesis predicts elevated levels of heterozygosity in the parthenogens compared to their respective sexual ancestor. Because little information exists on the genetic structure of parthenogenetic $C$. decisum, two questions with important evolutionary consequences are addressed. First, is parthenogenesis apomictic or automictic? Apomixis (ameiotic reproduction) should result in the retention of heterozygosity whereas automixis (various forms of meiotic reproduction and subsequent restoration of diploidy) should result in fixed homozygosity, although two forms of automixis, central fusion and premeiotic doubling, may allow retention of heterozygosity (Uzzel, 1970; Suomalainen et al., 1987). Apomictic parthenogenesis occurs in other populations of Campeloma decisum (Selander et al., 1977) and other Campeloma species (Mattox, 1937; Karlin et al., 1980. Secondly, the degree of clonal diversity is assessed within and among parthenogenetic populations, in an attempt to determine whether patterns of clonal diversity result from mutation, repeated hybridization events, or founding of clones by genetically divergent sexual ancestors (Moritz et al., 1989a).

\section{Tests of hypotheses for the maintenance of parthenogenesis in $C$. decisum}

Campeloma decisum is a freshwater, prosobranch snail endemic to lakes and rivers of eastern North America. The distribution of parthenogenetic and sexual populations was believed previously to follow a classical pattern of northern, parthenogenetic populations in glaciated regions and more southernly, sexual populations in unglaciated areas (van der Schalie, 1965; Bell, 1982). However, recent work has revealed that obligate parthenogenesis has arisen in southern populations of both C. decisum (Johnson, 1991; Fig. 1) and $C$. parthenum (Vail, 1979). The presence of parthenogens in unglaciated regions suggests that colonization of glaciated regions is unnecessary for the spread of parthenogenesis in this snail. Elsewhere, obligate parthenogenesis in this snail was postulated to have been maintained as a direct consequence of sterility selection against males by the metacercariae of Leucochloridiomorpha constantiae (Trematoda: Brachylaemidae), a digenetic trematode capable of sperm ingestion or sperm blockage in females (Johnson, 1991).

Parthenogenesis is assumed to have arisen spontaneously; therefore, heterozygosity should be similar to the sexual ancestral lineage. All parthenogenetic populations sampled throughout eastern North America were infected with unencysted metacercariae found in the brood chamber of female snails, whereas no individuals from sexual populations were infected with the metacercariae. The prevalence of infection (percentage of individuals infected) was often 70-80 per cent within host populations and the intensity of infection (mean number of metacercariae per host within host populations) usually ranged from 25-80 metacercariae per host. The prevalence of infection increased throughout the lifespan of individuals and snails were unable to reduce infections by immune response. Clearly, the high prevalence and intensity of infection could result in strong selection against males based on the following argument. It was reasoned that the historical introduction of this parasite into sexual snail populations resulted in strong selection for females capable of parthenogenetic reproduction because of the severe sperm limitation caused by this parasite. Metacercariae would have direct access to stored sperm in the seminal receptacle in female snails because the brood chamber and seminal receptacle are contiguous (S. G. Johnson personal observation; Vail, 1977).

\section{Materials and methods}

Allozyme variation was assessed for 358 snails from seven sexual populations and 11 parthenogenetic populations throughout the range of $C$. decisum (Appendix, Table A1; Fig. 1). For each population, 50-60 individuals were sexed, and parthenogenetic populations were defined by the absence of males, whereas sexual populations contained males (ranging from 25-55 per cent males). Populations with female- 
Fig. 1 Collection sites of parthenogenetic and sexual populations of $C$. decisum. See Appendix, Table Al for more exact location.

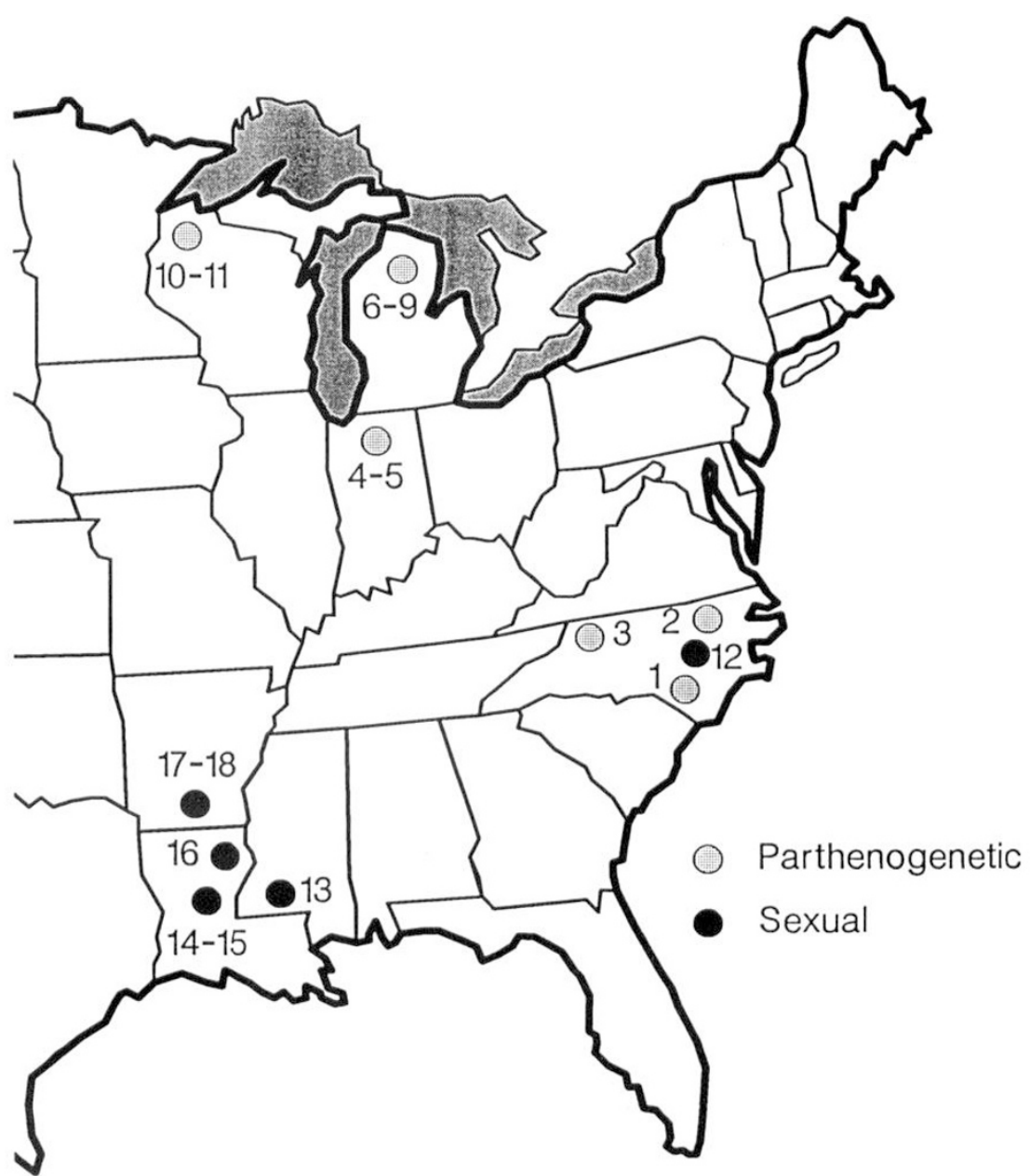

biased sex ratios may represent cases of mixtures of sexual and parthenogenetic females (Johnson, 1991). Parasitized tissues were removed from infected individuals and whole snails were stored in liquid nitrogen. They were placed at $-80^{\circ} \mathrm{C}$ upon return to the laboratory.

Homogenates of foot muscle, digestive gland, and gill were centrifuged the day prior to staining and the supernatant was stored at $-80^{\circ} \mathrm{C}$. Individual tissues consisting of the three tissue types were screened for tissue-specificity and, as a result of this screening, mixed-tissue homogenates were used.

Twenty individuals were scored for every population except Diamond Lake, WI and Chippewa River, WI $(n=19)$. Genetic variation at 19 presumptive genetic loci encoding 12 enzymes was assayed by horizontal starch gel (12 per cent) electrophoresis using standard staining techniques (Harris \& Hopkinson, 1976). Buffer systems and the presumptive gene loci are presented in the Appendix, Table A2.

Alleles at a locus were designated alphabetically in order of decreasing mobility; the most anodal locus in a system was numbered ' 1 ' with more cathodal loci receiving higher numbers. Calculations of individual heterozygosity $(H)$ and the percentage of loci polymorphic per population were estimated from individual genotypes of all loci for each population. Nei's genetic distance was calculated and phenetic relationships among all sexual and parthenogenetic populations were determined by UPGMA clustering (Sneath \& Sokal, 1973). All analyses were performed on the BIOSYs $=1$ package (Swofford \& Selander, 1989).

\section{Results}

\section{Genetic variation of sexual and parthenogenetic populations}

Parthenogenetic and sexual populations from southeastern regions (populations 1-3,12) are genetically identical at the 19 enzyme loci examined. They were monomorphic for the following alleles at the eight variable loci: $G 3 p h d^{\mathrm{A}}, 6-P g d h^{\mathrm{B}}, A c o n-1^{\mathrm{B}}, C k-1^{\mathrm{A}}$, Pgm-1 $1^{\mathrm{B}}$, Lap-1 ${ }^{\mathrm{A}}$, Est-1 ${ }^{\mathrm{A}}, I c d h-1^{\mathrm{B}}$ (Table 1). Parthen- 
ogens from Diamond Lake, WI (population 10) are entirely homozygous and differ from southeastern parthenogens only by the presence of $L a p-I^{\mathrm{B}}$. These fixed-homozygote parthenogens probably arose spontaneously and automictic parthenogenesis preserves homozygosity at these 19 loci.

Sexual populations from Mississippi, Louisiana, and Arkansas (populations 13-18) are nearly fixed for an alternative allele at these loci (Table 1). Parthenogenetic populations from Indiana and Michigan (populations 4-9) consist of individuals heterozygous at six or seven loci for the fixed alleles occurring in the southeastern and southern sexual populations. The pattern of elevated heterozygosity compared to sexual ancesters may indicate hybrid origins of these parthenogens and maintenance of elevated heterozygosity by apomictic parthenogenesis. Parthenogens from Chippewa River (population 11) are polyclonal, containing both homozygous individuals most similar to southeastern $C$. decisum and heterozygous individuals.

\section{Sources of genetic variation in parthenogenetic populations}

Only five multilocus genotypes were present among the 218 parthenogenetic individuals sampled (Table 2), a relatively low number of clones. There are two general classes of multilocus genotypes: homozygous genotypes and heterozygous genotypes. The single gene dif- ference at the Lap-1 between the two homozygous clones from North Carolina $(A B B A B A A B)$ and Wisconsin $(A B B A B B A B)$ populations suggests a very close genetic affinity. This slight difference may be attributable to mutation or founding by sexuals with different genotypes. Likewise the three heterozygous clones from Michigan and Indiana differ only at two enzyme loci (6-Pgdh and $I c d h-1)$. The multilocus genotype $C B C C C C C B$ may represent silencing of one allele at 6-Pgdh from the multilocus genotype $C C C C C C C B$. The Wolf Creek clone (CCCCCCCA) represents a slight divergence at the $I c d h-1$ locus.

\section{Genetic relatedness among sexual and parthenogenetic populations}

Three major clusters are evident in the phenogram (Fig. 2) based on Nei's genetic distances (Table 3): sexual populations and homozygous clones from North Carolina and Wisconsin, heterozygous clones from Michigan and Indiana, and sexual populations from the southern United States (compare Fig. 1). The separation of the Wisconsin clones from North Carolina populations is due to their slight, genetic differences at the Lap-1 locus. Within the heterozygous northern clones, the uniclonal populations (Potato Creek, Black Mallard, and Burt Lake) cluster and the polyclonal populations (Thunder Bay and Carp Lake River) cluster together. The southern, sexual popula-

Table 1 Allele frequencies at eight polymorphic loci in parthenogenetic and sexual populations of Campeloma decisum. $\mathrm{P}$ and $\mathrm{S}$ refer to parthenogenetic and sexual populations, respectively. See Appendix 1 for number designations and exact localities of
populations

Population

\begin{tabular}{llllllllllllllllllll} 
Locus & Allele & $1 \mathrm{P}$ & $2 \mathrm{P}$ & $3 \mathrm{P}$ & $4 \mathrm{P}$ & $5 \mathrm{P}$ & $6 \mathrm{P}$ & $7 \mathrm{P}$ & $8 \mathrm{P}$ & $9 \mathrm{P}$ & $10 \mathrm{P}$ & $11 \mathrm{P}$ & $12 \mathrm{~S}$ & $13 \mathrm{~S}$ & $14 \mathrm{~S}$ & $15 \mathrm{~S}$ & $16 \mathrm{~S}$ & $17 \mathrm{~S}$ & $18 \mathrm{~S}$ \\
\hline G3pdh & $\mathrm{A}$ & 1.00 & 1.00 & 1.00 & 0.50 & 0.50 & 0.50 & 0.50 & 0.50 & 0.50 & 1.00 & 0.76 & 1.00 & - & - & 0.03 & 0.03 & 0.05 & 0.05 \\
& $\mathrm{~B}$ & - & - & - & 0.50 & 0.50 & 0.50 & 0.50 & 0.50 & 0.50 & - & 0.24 & - & 1.00 & 1.00 & 0.97 & 0.97 & 0.95 & 0.95 \\
6-Pgdh & $\mathrm{A}$ & - & - & - & - & - & 0.40 & - & - & 0.43 & - & - & - & - & - & 0.00 & 0.03 & 0.13 & 0.13 \\
& $\mathrm{~B}$ & 1.00 & 1.00 & 1.00 & 1.00 & 1.00 & 0.60 & 1.00 & 1.00 & 0.57 & 1.00 & 1.00 & 1.00 & 1.00 & 1.00 & 1.00 & 0.97 & 0.87 & 0.87 \\
Acon-1 & $\mathrm{A}$ & - & - & - & 0.50 & 0.50 & 0.50 & 0.50 & 0.50 & 0.50 & - & 0.27 & - & 1.00 & 1.00 & 1.00 & 1.00 & 1.00 & 1.00 \\
& $\mathrm{~B}$ & 1.00 & 1.00 & 1.00 & 0.50 & 0.50 & 0.50 & 0.50 & 0.50 & 0.50 & 1.00 & 0.63 & 1.00 & - & - & - & - & - & - \\
Ck-1 & $\mathrm{A}$ & 1.00 & 1.00 & 1.00 & 0.50 & 0.50 & 0.50 & 0.50 & 0.50 & 0.50 & 1.00 & 0.76 & 1.00 & - & - & - & - & - & - \\
& $\mathrm{B}$ & - & - & - & 0.50 & 0.50 & 0.50 & 0.50 & 0.50 & 0.50 & - & 0.24 & - & 1.00 & 0.97 & 0.85 & 1.00 & 1.00 & 0.90 \\
& $\mathrm{C}$ & - & - & - & - & - & - & - & - & - & - & - & - & - & 0.03 & 0.15 & - & - & 0.10 \\
Pgm-1 & $\mathrm{A}$ & - & - & - & 0.50 & 0.50 & 0.50 & 0.50 & 0.50 & 0.50 & - & 0.21 & - & 1.00 & 1.00 & 0.97 & 1.00 & 1.00 & 0.97 \\
& $\mathrm{~B}$ & 1.00 & 1.00 & 1.00 & 0.50 & 0.50 & 0.50 & 0.50 & 0.50 & 0.50 & 1.00 & 0.79 & 1.00 & - & - & 0.03 & - & - & 0.03 \\
Lap-1 & $\mathrm{A}$ & 1.00 & 1.00 & 1.00 & 0.50 & 0.50 & 0.50 & 0.50 & 0.50 & 0.50 & - & 0.21 & 1.00 & - & - & - & - & - & - \\
& $\mathrm{B}$ & - & - & - & 0.50 & 0.50 & 0.50 & 0.50 & 0.50 & 0.50 & 1.00 & 0.79 & - & 1.00 & 1.00 & 1.00 & 1.00 & 1.00 & 1.00 \\
Est-1 & $\mathrm{A}$ & 1.00 & 1.00 & 1.00 & 0.50 & 0.50 & 0.50 & 0.50 & 0.50 & 0.50 & 1.00 & 0.79 & 1.00 & - & - & - & - & - & - \\
& $\mathrm{B}$ & - & - & - & 0.50 & 0.50 & 0.50 & 0.50 & 0.50 & 0.50 & - & 0.21 & - & 1.00 & 1.00 & 1.00 & 1.00 & 1.00 & 1.00 \\
lcdh-1 & $\mathrm{A}$ & - & - & - & - & 1.00 & - & - & - & - & - & - & - & 1.00 & 1.00 & 1.00 & 1.00 & 1.00 & 1.00 \\
& $\mathrm{~B}$ & 1.00 & 1.00 & 1.00 & 1.00 & - & 1.00 & 1.00 & 1.00 & 1.00 & 1.00 & 1.00 & 1.00 & - & - & - & - & - & - \\
\hline
\end{tabular}


Table 2 Allozymic heterozygosity, percentage polymorphic loci, non-random genotype frequencies, and clonal diversity in parthenogenetic and sexual populations of Campeloma decisum. Heterozygosity in parthenogenetic populations is based on direct counts

\begin{tabular}{|c|c|c|c|}
\hline Population & $\begin{array}{l}\text { Percentage } \\
\text { polymorphic }\end{array}$ & Heterozygosity & Clone \\
\hline \multicolumn{4}{|l|}{ Parthenogenetic } \\
\hline Waccamaw Lake, NC & 0.00 & 0.00 & $A B B A B A A B$ \\
\hline Flat River, NC & 0.00 & 0.00 & $A B B A B A A B$ \\
\hline S. Fork New River, NC & 0.00 & 0.00 & $A B B A B A A B$ \\
\hline Diamond Lake, WI & 0.00 & 0.00 & $A B B A B B A B$ \\
\hline Chippewa River, WI & 31.58 & 0.14 & $\begin{array}{l}A B B A B B A B(11) \\
C B C C C C C B(8)\end{array}$ \\
\hline Potato Creek, IN & 31.58 & 0.32 & $C B C C C C C B^{*}$ \\
\hline Black Mallard River, MI & 31.58 & 0.32 & $C B C C C C C B^{*}$ \\
\hline Burt Lake, MI & 31.58 & 0.32 & $C B C C C C C B^{*}$ \\
\hline Thunder Bay River, MI & 36.84 & 0.36 & $\begin{array}{l}C B C C C C C B^{*}(4) \\
C C C C C C C B(16)\end{array}$ \\
\hline Carp Lake River, MI & 36.84 & 0.36 & $\begin{array}{l}C B C C C C C B^{*}(3) \\
C C C C C C C B(17)\end{array}$ \\
\hline Wolf Creek, IN & 31.58 & 0.32 & $C B C C C C C A^{*}$ \\
\hline \multicolumn{4}{|l|}{ Sexual } \\
\hline Black River, NC & 0.00 & 0.00 & \\
\hline Tangipohoa River, MS & 0.00 & 0.00 & \\
\hline Old River, LA & 5.26 & 0.003 & \\
\hline Iatt River, LA & 15.79 & 0.019 & \\
\hline Bayou Bartholomew, LA & 10.53 & 0.005 & \\
\hline Ouachita River, AR & 10.53 & 0.017 & \\
\hline Saline River, AR & 21.05 & 0.029 & \\
\hline
\end{tabular}

*Indicates significant departure from Hardy-Weinberg equilibrium. Letters for multilocus clonal genotype refer to the 8 polymorphic loci in order of presentation in Table $1 . A=$ fast allele present, $B=$ slow allele present, $C=$ fixed heterozygote. See Appendix 1 for sample sizes.

Fig. 2 UPGMA cluster analysis of sexual and parthenogenetic populations of $C$. decisum based on Nei's genetic distances. Sexual populations are indicated by larger capital letters.

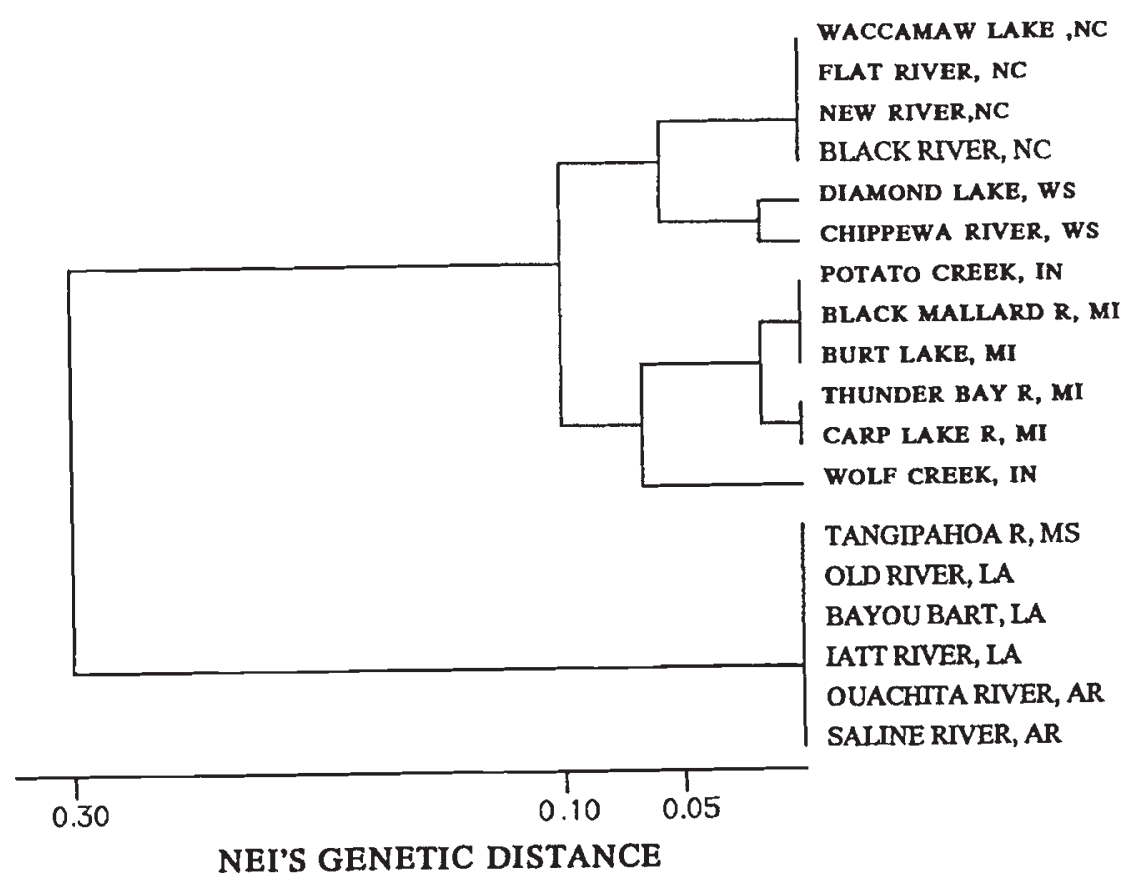


tions are quite genetically divergent from the southeastern sexual populations, suggesting that these groups of populations may represent cryptic species. There is, however, very little genetic differentiation among these sexual populations.

\section{Mode of parthenogenesis}

The presence of fixed frequencies $(0.5)$ for alternate alleles in the heterozygous parthenogens indicates apomictic parthenogenesis in which an unreduced egg undergoes mitotic divisions resulting in clonal replication of maternal genotypes. The fixed homozygosity at these 19 loci in various other parthenogens $(1-3$, $10-11)$ suggests that automixis may be the mode of reproduction, because we would expect some heterozygosity through accumulation of mutations in apomicts or central fusion automicts.

\section{Discussion}

This study provides critical evidence on the origins of parthenogenesis and the sources of genetic diversity within and among sexual and parthenogenetic populations of Campeloma decisum. Three salient results emerged from this study: first, the presence of two classes of parthenogens, fixed homozygotes and fixed heterozygotes, suggests that both the spontaneous origin of parthenogenesis and hybridization between sexual ancestors may have occurred; second, clonal diversity is minimal within and among parthenogenetic populations, with most of the clonal diversity stemming from variation present in ancestral sexual populations; lastly, cryptic allozyme variation exists between southeastern and southern sexual populations of $C$. decisum.

\section{Hybridization and the origin of parthenogenesis}

Numerous parthenogenetic taxa have dramatically higher levels of heterozygosity compared to their putative sexual ancestors and, furthermore, the gene combinations in parthenogenetic taxa are often derived from fixed alleles present in the ancestral sexual taxa (Schultz, 1969; White, 1973; Parker \& Selander, 1976; Vrijenhoek et al., 1977; Honeycutt \& Wilkinson, 1989; Moritz et al., 1989c). This pattern, derived mostly from unisexual vertebrates, focused attention on hybridization as a key factor in the origin of parthenogenesis. These results, however, suggest that, although hybridization between genetically divergent sexual ancestors may have been responsible for the origin of some parthenogens, hybridization is not necessary for the origin of parthenogenesis in $C$. decisum. The presence of fixed homozygotes at these 19 loci in parthenogens from North Carolina and Wisconsin, provides the strongest evidence that parthenogenesis can arise in the absence of hybridization. There is no indication that the North Carolina or Wisconsin clones are derived from hybridization, unless these parthenogens are derived from two sexual ancestors that are genetically identical at these 19 loci, but differ at other loci. Assuming these loci represent a somewhat random

Table 3 Nei's coefficient of genetic distance based on 19 presumptive genetic loci in parthenogenetic and sexual populations of C. decisum. Sample numbers correspond to those in Appendix 1

\begin{tabular}{|c|c|c|c|c|c|c|c|c|c|c|c|c|c|c|c|c|c|c|}
\hline Population & $\mathrm{P} 1$ & P2 & P3 & P4 & P5 & P6 & P7 & P8 & P9 & $\mathrm{P} 10$ & P11 & $\mathrm{S} 12$ & S13 & S14 & S15 & S16 & S17 & $\mathrm{S} 18$ \\
\hline P1 & - & 0.00 & 0.00 & 0.08 & 0.15 & 0.09 & 0.08 & 0.08 & 0.09 & 0.05 & 0.04 & 0.00 & 0.46 & 0.46 & 0.45 & 0.46 & 0.46 & 0.45 \\
\hline P2 & & - & 0.00 & 0.08 & 0.15 & 0.09 & 0.08 & 0.08 & 0.09 & 0.05 & 0.04 & 0.00 & 0.46 & 0.46 & 0.45 & 0.46 & 0.46 & 0.45 \\
\hline P3 & & & - & 0.08 & 0.15 & 0.09 & 0.08 & 0.08 & 0.09 & 0.05 & 0.04 & 0.00 & 0.46 & 0.46 & 0.45 & 0.46 & 0.46 & 0.45 \\
\hline P4 & & & & - & 0.06 & 0.01 & 0.00 & 0.00 & 0.06 & 0.08 & 0.02 & 0.08 & 0.15 & 0.15 & 0.14 & 0.15 & 0.15 & 0.15 \\
\hline P5 & & & & & - & 0.07 & 0.06 & 0.06 & 0.07 & 0.15 & 0.09 & 0.15 & 0.08 & 0.08 & 0.08 & 0.08 & 0.08 & 0.08 \\
\hline P6 & & & & & & - & 0.01 & 0.01 & 0.00 & 0.09 & 0.03 & 0.09 & 0.16 & 0.16 & 0.16 & 0.16 & 0.15 & 0.15 \\
\hline P7 & & & & & & & - & 0.00 & 0.01 & 0.08 & 0.02 & 0.08 & 0.15 & 0.15 & 0.14 & 0.15 & 0.15 & 0.15 \\
\hline P8 & & & & & & & & - & 0.01 & 0.08 & 0.02 & 0.08 & 0.15 & 0.15 & 0.14 & 0.15 & 0.15 & 0.15 \\
\hline P9 & & & & & & & & & - & 0.09 & 0.03 & 0.09 & 0.16 & 0.16 & 0.16 & 0.16 & 0.15 & 0.15 \\
\hline P10 & & & & & & & & & & - & 0.01 & 0.05 & 0.38 & 0.38 & 0.37 & 0.38 & 0.38 & 0.37 \\
\hline P11 & & & & & & & & & & & - & 0.05 & 0.25 & 0.25 & 0.24 & 0.25 & 0.25 & 0.24 \\
\hline $\mathrm{S} 12$ & & & & & & & & & & & & - & 0.46 & 0.46 & 0.45 & 0.46 & 0.46 & 0.45 \\
\hline S13 & & & & & & & & & & & & & - & 0.00 & 0.00 & 0.00 & 0.00 & 0.00 \\
\hline S14 & & & & & & & & & & & & & & - & 0.00 & 0.00 & 0.00 & 0.00 \\
\hline S15 & & & & & & & & & & & & & & & - & 0.00 & 0.00 & 0.00 \\
\hline S16 & & & & & & & & & & & & & & & & - & 0.00 & 0.00 \\
\hline S17 & & & & & & & & & & & & & & & & & - & 0.00 \\
\hline
\end{tabular}


survey, the probability seems minuscule that two sexual species would not differ at these loci.

It has been postulated that there was strong selection for the spontaneous origin of obligate parthenogenesis in $C$. decisum in response to male sterility caused by the unencysted metacercariae of a digenetic trematode, Leucochloridiomorpha constantiae. The presence of fixed homozygotes in North Carolina and Wisconsin is consistent with this spontaneous hypothesis. The presence of highly heterozygous individuals from northern populations may indicate dual origins of parthenogenesis in $C$. decisum. However, a complementary hypothesis involving male sterility by the digenetic trematode and secondary hybridization (sensu Cuellar, 1977) by genetically distinct males is possible.

The critical question is whether parthenogenesis arose as a by-product of impaired meiosis due to hybridization. The pattern of heterozygous genotypes can be readily explained by the fertilization of a diploid parthenogenetic female, which arose by parasitic castration, by males with the opposite alleles fixed. Incorporation of the divergent paternal genome and maintenance of parthenogenetic reproduction would produce heterozygous, triploid genotypes. There is no convincing evidence from the intensity of protein staining to indicate polyploidy. The hypothesis assumes that dispersal of parthenogenetic diploid females, probably from the southeastern populations, results in contact with sexual individuals from the southern states. This hypothesis predicts a hybrid zone between parthenogenetic and sexual populations. Flow cytometry could be used to address the hypothesis that heterozygous individuals are triploid, and may be rejected if heterozygous individuals are diploid. Varying ploidy levels occurred in C. parthenum (Dougherty, 1982); parthenogenetic C. rufum were diploid (Mattox, 1937). An analysis of mtDNA can address the prediction from the secondary hybridization hypothesis that the maternal genome should be derived from southeastern parthenogens.

\section{Modes of parthenogenesis and the origin of clonal diversity}

A surprising result of this study was the relatively low clonal diversity within and among parthenogenetic populations. The gene combinations in the five homozygous and heterozygous clones of $C$. decisum are all found in the sexual lineages in the southeastern and southern United States and, therefore, mutation has not generated significant clonal diversity. That most of the clonal variability is derived from sexual lineages also suggests a relatively recent origin of these parthenogens. Recent work on cladocerans (Crease et al.,
1989; Hebert et al., 1989), ostracods (Havel \& Hebert, 1989), grasshoppers (Honeycutt \& Wilkinson, 1989), and a variety of vertebrates (Dawley \& Bogart, 1989), revealed much higher levels of clonal diversity than that of $C$. decisum, with clonal variability being generated by repeated hybridization between sexual lineages. The low clonal diversity in $C$. decisum is probably attributable to two causes: parthenogenesis arising in the absence of hybridization and, where hybridization has occurred, the sexual ancestral lineages in the southeastern and southern state having low levels of genetic variation.

Different modes of parthenogenesis (automictic versus apomictic) in C. decisum are implicated by the presence of homozygous clones (North Carolina and Wisconsin) and highly heterozygous clones (Indiana, Michigan, and Wisconsin). The only likely mechanism of automictic parthenogenesis which preserves heterozygosity is central fusion of two polar nuclei providing that the initial mother is heterozygous and there is no recombination between the locus and the centromere (Suomalainen et al., 1987). Apomictic reproduction occurs in C. rufum (Mattox, 1937), C. decisum in New York (Selander et al., 1977) and C. parthenum (Karlin et al., 1980).

\section{Cryptic species of Campeloma}

The taxonomic status of many species of Campeloma remains unclear (Vail, 1979; Burch, 1989). Recent revisions have resulted in grouping many northern species into $C$. decisum, presumably because the morphological characters used to differentiate these taxa were phenotypically plastic (Burch, 1989). The allozyme analysis in this study revealed genetic distances of $0.45-0.46$ between the southeastern and southern sexuals. These populations have diverged considerably, and probably represent distinct species. Clearly, a thorough revision of the whole genus using molecular analysis should resolve the uncertain status of Campeloma species.

\section{Acknowledgements}

I gratefully acknowledge $\mathrm{H}$. Alexander, K. Armitage, T. Echelle, R. Holt, R. F. Johnston, C. Lively, and C. Moritz for their comments on various stages of the manuscript. A special thanks is due to T. Titus for sharing his wisdom on electrophoresis. I owe a debt of gratitude to The Museum of Natural History and the Department of Systematics and Ecology of the University of Kansas, Sigma Xi, the Theodore Roosevelt Fund of the American Museum of Natural History, The University of Michigan Biological Station, and the 
Naturalist-Ecologist Training Program of CarnegieMellon and The University of Michigan Biological Station for the financial support of these endeavours.

\section{References}

BELL, G. 1982. The Masterpiece of Nature: The Evolution and Genetics of Sexuality. University of California Press, Berkeley.

BURCH, J. B. 1989. North American Freshwater Snails. Malacological Publications, Hamburg, Michigan, USA.

CARSON, H. L. 1967. Selection for parthenogenesis in Drosophila mercatorum. Genetics, 55, 157-171.

CREASE, T. J., STANTON, D. J. AND HEBERT, P. D. N. 1989. Polyphyletic origins of asexuality in Daphnia pulex. II. Mitochondrial-DNA variation. Evolution, 43, 10161026.

Cuellar, o. 1977. Animal parthenogenesis. Science, 197, 837-843.

DAWLEY, R. M. AND BOGART, J. P. (EDS.). 1989. Evolution and Ecology of Unisexual Vertebrates. The New York State Museum Bulletin 466, Albany, NY.

DOUGHERTY, B. J. 1982. Comparative karyology of some sexual and parthenogenetic Campeloma (Mesogastropoda: Viviparidae) in the southeastern United States. M. S. Thesis, Florida State University.

GLESENER, R. R. AND TILLMAN, D. 1978. Sexuality and the components of environmental uncertainty: Clues from geographic parthenogenesis in terrestrial animals. Am. Nat., 112, 659-673.

HARRIS, H. AND HOPKINSON, D. A. 1976. Handbook of Enzyme Electrophoresis in Human Genetics. North-Holland Publishing Co., Amsterdam, Netherlands.

HAVEL, J. E. AND HEBERT, P. D. N. 1989. Apomictic parthenogenesis and genotypic diversity in Cypridopsis vidua (Ostracoda: Cyprididae). Heredity, 62, 383-392.

HEBERT, P. D. N., BEATON, M. J., SCHWARTZ, S. S. AND STANTON, D. J. 1989. Polyphyletic origins of asexuality in Daphnia pulex. I. Breeding-system variation and levels of clonal diversity. Evolution, 43, 1004-1015.

HEwITT, G. M. 1975. A new hypothesis for the origins of the parthenogenetic grasshopper Moraba virgo. Heredity, 34, 117-123.

HONEYCUTT, R. L. AND WILKINSON, P. 1989. Electrophoretic variation in the parthenogenetic grasshopper Warramaba virgo and its sexual relatives. Evolution, 43, 1027-1044.

JOHNSON, S. G. 1991. Digenean parasitism and the origin and consequences of apomictic parthenogenesis in a freshwater snail, Campeloma decisum. Ph.D. Thesis, University of Kansas.

KARLIN, A. A., VAIL, V. A. AND HEARD, W. H. 1980. Parthenogenesis and biochemical variation in southeastern Campeloma geniculum (Gastropoda: Viviparidae). Malacol. Rev., 13, 7-15.

LEVIN, D. A. 1975. Pest pressure and recombination systems in plants. Am. Nat., 109, 437-451.

LIVELY, C. M. 1987. Evidence from a New Zealand snail for the maintenance of sex by parasitism. Nature, 328, 519-521.
LLOYD, D. 1980. Benefits and handicaps of sexual reproduction. Evol. Biol., 13, 69-111.

matTox, N. т. 1937. Oogenesis of Campeloma rufum, a parthenogenetic snail. Z. Zellforsch. Mikrosk. Anat., 27, 455-464.

MORITZ, c. 1983. Parthenogenesis in the endemic Australian lizard Heteronotia binoei (Gekkonidae). Science, 220 , 735-737.

MORITZ, C., BROWN, W. M., DENSMORE, L. D., WRIGHT, J. W., VYAS, D., DONNELLAN, S., ADAMS, M. AND BAVERSTOCK, P. 1989a. Genetic diversity and the dynamics of hybrid parthenogenesis in Cnemidophorus (Teiidae) and Heteronotia (Gekkonidae) In: Dawley, R. M. and Bogart, J. P. (eds) Evolution and Ecology of Unisexual Vertebrates. Bulletin 466, New York State Museum, Albany, New York, pp. 87-112.

MORITZ, C., WRIGHT, J. w. AND BROWN, W. M. 1989b. Mitochondrial-DNA analyses and the origin and relative age of parthenogenetic lizard (Genus Cnemidophorus). III. $C$. velox and C. exsanguis. Evolution, 43, 958-968.

MORITZ, C., DONNELLAN, S., ADAMS, M. AND BAVERSTOCK, P. R. 1989c. The origin and evolution of parthenogenesis in Heteronotia binoei (Gekkonidae): Extensive genotypic diversity among parthenogens. Evolution, 43, 994-1003.

PARKER, E. D. JR AND SELANDER, R. K. 1976. The organization of genetic diversity in the parthenogenetic lizard Cnemidophorus tesselatus. Genetics, 84, 791-805.

SCHULTZ, R. J. 1969. Hybridization, unisexuality, and polyploidy in the teleost Poeciliopsis (Poeciliidae) and other vertebrates. Am. Nat., 103, 605-619.

SELANDER, R. K., PARKER, E. D. AND BROWNE, R. A. 1977. Clonal variation in the parthenogenesis snail Campeloma decisa (Viviparidae). Veliger, 20,349-351.

SELANDER, R. K., SMITH, M. H., YANG, S. Y. JOHNSON, W. E. AND GENTRY, J. B. 1971. Biochemical polymorphism and systematics in the genus Peromyscus. I. Variability in the old-field mouse (Peromyscus polionotus). Univ. Texas Pub., 7103, 49-90.

SNEATH, P. H. A. AND SOKAL, R. R. 1973. Numerical Taxonomy. Freeman, San Francisco.

Stebbins, G. L. 1950. Variation and Evolution in Plants. Columbia University Press, New York.

SUOMAlainen, E. AND SAURA, A. 1973. Genetic polymorphism and evolution in parthenogenetic animals. I. Polyploid Curculionidae. Genetics, 74, 489-508.

SuOMAlainen, E., SAURA, A. AND LOKKI, J. 1987. Cytology and Evolution in Parthenogenesis. CRC Press, Boca Raton, FL.

SWOFFORD, D. AND SELANDER, R. B. 1989. BIOSYS-1. Illinois Natural History Survey. Champaign, IL.

TEMPLETON, A. R. 1982. The prophecies of parthenogenesis. In: Dingle, H. and Hegman, J. P. (eds) Evolution and Genetics of Life Histories. Springer-Verlag, New York, pp. 75-101.

TEMPleton, A. R., CARSON, H. L. AND Sing, C. F. 1976. The population genetics of parthenogenetic strains of Drosophila mercatorum. II. The capacity for parthenogenesis in a natural, bisexual population. Genetics, 82, 527-542.

UZZELL, T. 1990. Meiotic mechanisms of naturally occcuring unisexual vertebrates. Am. Nat., 104, 433-445.

vall, v. 1977. Comparative reproductive anatomy of 3 vivi- 
parid gastropods. Malacologia, 16, 519-540.

vAIL, v. A. 1979. Campeloma parthenum (Gastropoda: Viviparidae), a new species from north Florida. Malacol. Rev., $12,85-86$.

VAN DER SCHALIE, H. 1965. Observations on the sex of Campeloma (Gastropoda: Viviparidae). Occ. Pap. Mus. Zool. Univ. Mich., 641, 1-15.

\section{Appendix}

Table A1 Collection localities for parthenogenetic (1-11) and sexual (12-18) populations of $C$. decisum. All sample sizes are 20 individuals except for Diamond Lake and Chippewa River $(n=19)$. P and S refer to parthenogenetic and sexual populations, respectively

\begin{tabular}{ll}
\hline $\begin{array}{l}\text { Sample } \\
\text { Number }\end{array}$ & Population \\
\hline P1 & Waccamaw Lake, Columbus Co., NC \\
P2 & Flat River, Person Co., NC \\
P3 & South Fork New River, Ashe Co., NC \\
P4 & Potato Creek, St Joseph Co., IN \\
P5 & Wolf Creek, Marshall Co., IN \\
P6 & Thunder Bay River, Alpena Co., MI \\
P7 & Black Mallard River, Presque Isle Co., MI \\
P8 & Burt Lake, Cheboygan Co., MI \\
P9 & Carp Lake River, Emmet Co., MI \\
P10 & Diamond Lake, Vilas Co., WS \\
P11 & Chippewa River, Sawyer Co., WS \\
S12 & Black River, Sampson Co., NC \\
S13 & Tangipahoa River, Pike Co., MS \\
S14 & Old River, LaSalle Parish, LA \\
S15 & Iatt River, Grant Parish, LA \\
S16 & Bayou Bartholomew, Morehouse Parish, LA \\
S17 & Ouachita River, Ashley Co., AR \\
S18 & Saline River, Bradley Co., AR \\
\hline
\end{tabular}

VRIJENHOEK, R. C., ANGUS, R. A. AND SCHULTZ, R. J. 1977. Variation and heterozygosity in sexually vs. clonally reproducing populations of Poeciliopsis. Evolution, 31, 767-781.

white, M. J. D. 1973. Animal Cytology and Evolution. Cambridge University Press, Cambridge.

Table A2 Enzyme systems and buffers used in horizontal starch gel electrophoresis of Campeloma decisum. Running and voltage for each buffer were TC-EDTA $(6 \mathrm{~h}$ at $120 \mathrm{~V})$ and $\mathrm{LiOH}(5 \mathrm{~h}$ at $160 \mathrm{~V})$.

\begin{tabular}{ll}
\hline Buffer & Enzyme system \\
\hline Tris-citrate EDTA, PH 7.2 (135 mM) & Aconitase (Acon-1, Acon-2) \\
Tris, 45 mM citrate, 1.3 mM EDTA; gel 1:15 dilution) & Creatine kinase(Ck) \\
& Glycerol-3-phosphate dehydrogenase (G3pdh) \\
& Isocitrate dehydrogenase (Icdh-1, Icdh-2) \\
& Malate dehydrogenase (Mdd-1, Mdh-2) \\
& 6-Phosphogluconate dehydrogenase (6-Pgd) \\
Lithium hydroxide (Selander et al., 1971) & Phosphoglucomutase (Pgm) \\
& Esterases (Est-1, Est-2) \\
& Leucine aminopeptidase (Lap-1, Lap-2) \\
& Leucine-glycine-glycine (Pep-B) \\
& Phosphoglucose isomerase (Pgi) \\
& Pro-leu (Pep-A, Pep-C) \\
& Superoxide dismutase (Sod-1)
\end{tabular}

